\title{
8 \\ Japan: The Political Costs of Deterrence
}

\author{
Tomohiko Satake'
}

This chapter analyses the US-Japan alliance and the continuing limits to Japan's contribution to the operational underpinnings of deterrence. While Japan's security environment has deteriorated in recent years, and although increased interoperability between the Japan Self-Defense Forces (SDF) and the US military has been achieved, there remain significant normative and constitutional constraints on Tokyo's ability to play an active military role in North-East Asia and beyond. Unless the Japanese Government undertakes significant reform of its security policy, it is likely that the US-Japan alliance will continue to be characterised by asymmetry in the foreseeable future.

\section{From an Asymmetric to a Symmetric Alliance?}

The US-Japan alliance, based on the US-Japan Security Treaty concluded in 1951 and renewed in 1960, is typified by its asymmetric defence obligations. Article 5 of the treaty states that Japan and the US would respond to armed attacks only 'in the territories under the administration

1 The views expressed in this chapter are those of the author and do not reflect the official views of NIDS or Ministry of Defence, Japan. 
of Japan'. This means that the SDF has no legal obligation to protect the US homeland or the US military outside Japanese territory, while the US military is required to protect the Japanese homeland.

To offset these unilateral defence obligations, Article 6 of the treaty grants the US the use of land, air and naval forces of facilities and areas in Japan'. These facilities are not only for the defence of Japan, but also for international peace and security in the 'Far East'. As a result, the alliance came to consist of what is called 'asymmetric mutuality' —often described as the 'exchange between mono (materials, meaning US military bases) and hito (people, meaning US soldiers)'. ${ }^{2}$

However, Japan has gradually but surely expanded its security roles within the framework of the US-Japan alliance, especially since the end of the Cold War. After the 1991 Gulf War, Japan dispatched its Maritime SDF (MSDF) minesweepers to the Gulf of Aden in the Middle East for the first time. And, after the 1993-94 nuclear crisis on the Korean Peninsula, it enabled the SDF to provide logistical support to the US military in case of 'situations in areas surrounding Japan' (Syuhen-Jitai) that would have 'an important influence on Japanese peace and security'. ${ }^{3}$ Further, after the 11 September 2001 terrorist attacks in the US, Japan dispatched MSDF refuelling ships to the Indian Ocean to contribute to the US-led multilateral military operation known as Enduring Freedom. Japan also dispatched Ground SDF units for reconstruction efforts in Iraq from 2003 to 2009.

Japan's security roles under the US-Japan alliance further expanded under Prime Minister Shinzo Abe's leadership. After being re-elected as Japanese prime minister in December 2012, Abe forcefully promoted Japan's defence reforms, including the build-up of defence capabilities. Those capabilities included the acquisition of 105 F-35 jet fighters, construction of the largest-ever Izumo-class multipurpose destroyers, establishment of the amphibious rapid deployment force, introduction of long-range stand-off missiles and development of a hypersonic anti-ship missile.

The Abe government also revised Japan's National Defense Program Guidelines (NDPG) twice, in 2013 and in 2018. The 2018 NDPG introduced the Multi-Domain Defence Force concept to enhance the SDF's joint operational capabilities across ground, maritime, air, cyber

2 Sakamoto Kazuya, Nichibei Domei no Kizuna: Anpo Joyaku to Sougosei no Mosaku [The Bond of the US-Japan Alliance: The Security Treaty and Search for Mutuality] (Tokyo: Yuhikaku, 2001), 63. 3 Ministry of Foreign Affairs of Japan, 'The Guidelines for Japan-US Defense Cooperation', 23 September 1997, www.mofa.go.jp/region/n-america/us/security/defense.html. 
and space domains. ${ }^{4}$ Under this initiative, Japan invested heavily in new domains such as cyber, space and electromagnetic. In May 2020, the SDF launched a Space Domain Mission Unit specialising in space security. To financially support such initiatives, Japan boosted its defence budget for nine consecutive years after 2012 .

The Abe government introduced new security legislation that allowed Japan to exercise the right of collective self-defence for the first time in its history. Japan is now able to mobilise the SDF in case of an 'armed attack against a country other than Japan', as stipulated by the US-Japan defence guidelines updated in April 2015. ${ }^{5}$ The new guidelines, as well as the new security legislation, enable the SDF to protect the military assets of the US and its partners during peacetime and in 'grey-zone' situations (which occur in neither peace nor wartime). In fact, the SDF has already conducted a number of 'asset protection' missions for vessels and aircraft of the US military. ${ }^{6}$

The new guidelines also realised more 'seamless' coordination between the SDF and the US military from peacetime to wartime by establishing the Alliance Coordination Mechanism (ACM). The ACM comprises policy, operational and military coordination groups. Unlike the previous Bilateral Coordination Mechanism, which could only function during emergencies, the ACM operates from peacetime and covers a wide range of incidents, including grey-zone situations. Indeed, the ACM was utilised for policy coordination after the North Korean nuclear test in January 2016. Japan and the US also agreed to establish a bilateral planning mechanism to prepare for various contingencies. ${ }^{7}$

As such, Japan has enhanced its roles, missions and capabilities under the US-Japan alliance, while continuously relying on US extended deterrence. With Japan's greater defence and security roles, and with enhanced coordination and integration between the SDF and the US

4 Ministry of Defense of Japan, 'National Defense Program Guidelines', 18 December 2019, www. mod.go.jp/en/d_act/d_policy/national.html.

5 Ministry of Foreign Affairs of Japan, 'The Guidelines for Japan-US Defense Cooperation', 27 April 2015, www.mofa.go.jp/files/000078188.pdf.

6 Elizabeth Shim, 'Report: Japan Increased Protection of US Military Assets after 2016', UPI, 29 March 2019, www.upi.com/Top_News/World-News/2019/03/29/Report-Japan-increasedprotection-of-US-military-assets-after-2016/3861553864841/.

7 Ministry of Foreign Affairs of Japan, 'The Guidelines for Japan-US Defense Cooperation', 4. 
military, some argue that the US-Japan alliance is no longer 'asymmetric', but has moved towards a 'more balanced, integrated, and coordinated security' partnership. ${ }^{8}$

\section{Japan's Pacifism Remains Strong}

Despite significant developments in alliance cooperation, some continuities exist in the US-Japan security relationship. Most notably, Japan's strong pacifism and anti-militarism, which originated from the devastating defeat of World War II, still constrain Japan's security policies. ${ }^{9}$ Japan's pacifism and anti-militarism can be understood as the Japanese public's tendency to believe that the:

Military is a dangerous institution that must be constantly restrained and monitored lest it threaten Japan's postwar democratic order and undermine the peace and prosperity that the nation has enjoyed since $1945 .{ }^{10}$

As will be discussed below, this belief has gradually changed over the past decades. Nevertheless, it still limits the utility of the US-Japan alliance by increasing the political (and sometimes financial) costs of Japan's deterrence to an unacceptable level for the Japanese Government.

Since the end of the Cold War, and in the face of an increasingly assertive China and North Korea, the Japanese public has gradually become supportive of a more realistic security policy for Japan. The Japanese public's impression of, and attitude towards, the SDF greatly improved in the wake of the SDF's massive rescue mission during the Great East Japan Earthquake in March 2011 and has continued to improve. Yet, during debates over the new security legislation, the Japanese Government faced a concerted anti-legislation campaign by members of the Japanese

8 Congressional Research Service, 'The US-Japan Alliance', updated 13 June 2019, fas.org/sgp/ crs/row/RL33740.pdf.

9 For Japan's pacifism and anti-militarism, see Thomas Berger, 'From Sword to Chrysanthemum: Japan's Culture of Anti-Militarism', International Security 17(4), 1993, 119-50, doi.org/10.2307/2539024; Peter Katzenstein, Cultural Norms and National Security: Police and Military in Postwar Japan (Ithaca: Cornell University Press, 1998); Peter Katzenstein and Nobuo Okawara, Japan's National Security: Structures, Norms and Policy Responses in a Changing World (Ithaca: Cornell University Press, 2010).

10 Berger, 'From Sword to Chrysanthemum', 120. 
public, intellectuals and politicians. ${ }^{11}$ This caused considerable political turbulence when the new security legislation was passed in the Diet in September 2015. ${ }^{12}$ According to one survey, the Cabinet's support rate dropped 6 percentage points while its disapproval rate increased 7 points after the passage of the legislation. ${ }^{13}$

After five years, the Japanese public seem to have accepted the legislation. A survey conducted in December 2020 revealed that 46 per cent of respondents approved of the 2015 security legislation, while 33 per cent disapproved of it. ${ }^{14}$ Nevertheless, the 2015 incident revealed that, despite an increasingly severe security environment, Japanese policymakers should expect opposition if they want to change Japanese security policies that conflict with Japan's pacifism, which stems from Article 9 of the Constitution of Japan.

Recent examples of such normative constraints include the cancellation of plans to acquire the land-based Aegis Ashore Ballistic Missile Defence system in June 2020. According to the government's explanation, the major reason for the cancellation was the extra expense and time needed to ensure that rocket boosters used to launch the interceptor missiles would not fall on residential areas. ${ }^{15}$ While the government must endeavour to safeguard lives in the local community, assuring 'zero-risk', especially in an emergency situation in which ballistic missiles have already flown to Japan, is hard to achieve, as intercepted missiles could also cause debris that may fall on residential areas. Although logical, such an argument is unlikely to become mainstream in Japanese society. One survey showed that 51 per cent of respondents supported the government's decision to withdraw the plan,

11 'Massive Protest Against Japanese Military Legislation', VOA News, 30 August 2015, www.voanews. $\mathrm{com} / \mathrm{a} /$ massive-protest-against-japanese-military-legislation/2938322.html. For the opposition from scholars, see 'Association of Scholars Opposed to the Security-Related Bills', 15 June 2015, anti-securityrelated-bill.jp/index_en.html.

12 Yuki Oda and Anna Fifield, 'Protests Erupt in Japan as Committee in Parliament Approves Security Bills', The Washington Post, 15 July 2015, www.washingtonpost.com/world/asia_pacific/ protests-erupt-in-japan-as-committee-in-parliament-approves-security-bills/2015/07/15/7267d88e2afd-11e5-960f-22c4ba982ed4_story.html.

13 'Support for Japan's Abe Sags after Security Bills Passed', Reuters, 21 September 2015, www. reuters.com/article/us-japan-security-idUSKCN0RL08Z20150921.

14 See the result of a public opinion survey by Asahi conducted in November 2020, digital.asahi. com/articles/DA3S14736112.html [in Japanese].

15 'Kono Suspends Deployment of Aegis Ashore Defense System', Asahi Shimbun, 16 June 2020, www.asahi.com/ajw/articles/13462150 (site discontinued). 
while only 29 per cent opposed the decision. ${ }^{16}$ Consequently, the Japanese Government has been forced to consider an alternative plan, which is said to be even more costly than the original Aegis Ashore plan.

Another example is discussion over the introduction of 'enemy-bases strike capabilities' or teki-kichi kogeki noryoku. This debate has been ongoing for more than a decade, with some Liberal Democratic Party (LDP) politicians pushing for an increase in Japan's strategic options in an era of uncertainty. The SDF's strike capabilities, however limited, are expected to transform a traditional division of labour in the US-Japan alliance, which delegated the 'spear' role of offensive capability to the US and the 'shield' role of self-defence to Japan. ${ }^{17}$ By building offensive capabilities, Japan could enhance its own deterrence capabilities while, at the same time, strengthening the alliance beyond a previous paradigm of role-sharing. Having offensive (or 'counter-striking') weapons could also save deterrence costs, which have been heavily dependent upon a costly missile defence system.

However, the introduction of enemy-bases strike capabilities met strong opposition inside and outside the Japanese Government. The LDP's coalition partner, the New Komei Party, stressed Japan's diplomatic efforts to forge a peaceful environment over acquiring its own deterrence capabilities. Some Japanese media outlets, including the Asahi newspaper, also opposed the plan, arguing that it would destabilise the region by promoting an arms race. ${ }^{18}$ The Japanese public seemed to have had mixed feelings about the plan. One survey showed that 55 per cent of respondents were against initiating enemy-bases strike capabilities, while 37 per cent were in favour. ${ }^{19}$ Another survey found that 50 per cent of respondents agreed that Japan should have 'capabilities to prevent enemy's attacks on its soil'. ${ }^{20}$

Given the controversial nature of the proposal, the Suga administration decided to postpone the decision to introduce strike capabilities, originally scheduled for the end of 2020. While the Japanese Government

16 The survey by the Japanese TV station can be seen at news.tbs.co.jp/newsi_sp/yoron/ backnumber/20200704/q4-1.html [in Japanese].

17 James L. Schoff and David Song, 'Should the US Share the "Spear” With Japan?', Japan Times, 9 May 2017, www.japantimes.co.jp/opinion/2017/05/09/commentary/japan-commentary/u-s-sharespear-japan/.

18 'Allowing SDF to Strike Enemy Bases Would Alter Security Policy', Asahi Shimbun, 21 July 2020, www.asahi.com/ajw/articles/13564486 (site discontinued).

19 Survey by Nikkei newspaper, 20 July 2020, www.nikkei.com/article/DGXMZO61703540 Z10C20A7PE8000 [in Japanese].

20 The result can be seen at www.nhk.or.jp/senkyo/shijiritsu/archive/2020_08.html [in Japanese]. 
did decide to introduce long-range, stand-off missiles, it explained that they were designed to deal with ships and landing forces attempting to invade Japan, including remote islands, from the outside of their threat envelopes. ${ }^{21}$ Defence Minister Nobuo Kishi made it clear that Japan's stand-off missiles were not aimed at 'so-called enemy-bases strikes'. ${ }^{22}$

In the late 1960s and early 1970s, Japan undertook high-level studies to ascertain the costs and benefits of manufacturing a threshold nuclear capability, and national elites determined that such assessments did not justify a departure from Japan's non-nuclear stance. ${ }^{23}$ In June 1976, Japan ratified the Treaty on the Non-Proliferation of Nuclear Weapons. Before the ratification, the Japanese Diet confirmed the implementation of 'Three Non-Nuclear Principles' that had originally been adopted in 1968, and pledged not to manufacture, possess or permit the introduction of nuclear weapons on Japanese soil. These principles have been widely supported by the Japanese public as they symbolise Japan's non-nuclear policy.

Today, Japan's so-called nuclear allergy remains strong, and has even increased since the disruption of the Fukushima Nuclear Reactor by the earthquake and tsunami in March 2011. According to a joint survey conducted by Japanese and American research institutes in 2017, given North Korea's nuclear development, 40 per cent of American respondents supported Japan's nuclear armament and 33 per cent were against it. By contrast, 69 per cent of Japanese respondents were against Japan's nuclear armament and only 12 per cent supported it. ${ }^{24} \mathrm{~A}$ more recent survey found that nearly 60 per cent of Japanese respondents supported Japan signing the Treaty on the Prohibition of Nuclear Weapons, which entered into force in January 2021. ${ }^{25}$

Japan's anti-militarism and nuclear allergy limit Japanese and American strategic options. Following the end of the Intermediate-Range Nuclear Forces Treaty, the US reportedly considered deploying ground-based, intermediate-range missiles among its Asian allies, including Japan.

21 Ministry of Defense of Japan, Defense of Japan 2019, 221.

22 Ministry of Defense of Japan, 'Boei Daijin Kisya Kaiken' [Press Conference of Defense Minister], 11 December 2020, www.mod.go.jp/j/press/kisha/2020/1211a.html [in Japanese].

23 Akira Kurosaki, 'Nuclear Energy and Nuclear Weapons Potential: A Historical Analysis of Japan in the 1960s', The Nonproliferation Review 24(1/2), 2017, 52-54, doi.org/10.1080/10736700.2017. 1367536.

24 The Genron NPO and Critical Issues Poll, 'US-Japan Opinion Survey 2017', 8 January 2018, www.genron-npo.net/en/US-Japan_2017.pdf (site discontinued).

25 'Survey: 51\% Oppose Extension of "Go to Travel" Campaign', Asahi Shimbun, 17 November 2020, www.asahi.com/ajw/articles/13938137 (site discontinued). 
The point would be to offset the 'strike gap' between China's ground-based strike power and America's air and sea-launched strike power. ${ }^{26}$ It would also fill the strategic gap between the US, whose military bases in Asia are quite vulnerable to missile attacks by enemies, and China, which has vast strategic depth in its homeland. ${ }^{27}$ Yet, the introduction of US offensive weapons on Japanese soil—even without nuclear warheadscould provoke a domestic counter-movement or at least vocal resistance by local communities. ${ }^{28}$ While Japan has decided to develop its own long-range missiles, it is not clear to what extent those missiles can fulfil the abovementioned strategic gaps.

\section{Legal Constraints}

In addition to the Japanese public's anti-militaristic sentiment, legal constraints on Japan's defence policies remain strong, even after the introduction of the new security legislation. These legal impediments could limit the SDF's ability to escalate in a timely manner from peacetime to wartime, including in grey-zone situations.

As already stated, the new security legislation enables the SDF to protect military assets of foreign countries, including Australia, during peacetime or grey-zone operations. However, such operations are limited to the protection of foreign countries that engage in 'activities that contribute to the defence of Japan'. They are also limited to 'activities in the scene where the combat activities are actually being conducted'. Further, the legislation stipulates that operations should be immediately terminated once a conflict breaks out between foreign defence forces and enemy countries. ${ }^{29}$

The SDF is allowed to use force once foreign countries conduct an 'organised and planned' armed attack against Japan. However, the question

26 Sugio Takahashi and Eric Sayers, 'America and Japan in a Post-INF World', War on the Rocks, 8 March 2019, warontherocks.com/2019/03/america-and-japan-in-a-post-inf-world/.

27 Ken Jimbo, 'Post-INF Zenpai Joyaku: Saihaibi de Kinko Mosaku Ka' [Post-INF Treaty: Seeking a Balance by the Redeployment?], The Canon Institute for Global Studies, 2 April 2019, cigs.canon/ article/20190402_5711.html [in Japanese].

28 Koji Sonoda and Taketsugu Sato, 'Bei, Taichu Misairmou Keikaku Haibisaki, Nihonwa "Saiyuryokukouho"' [The United States' Missile Network Planning against China: Japan is the 'Most Likely Candidate'], Asahi Shimbun Digital, 8 July 2020, digital.asahi.com/articles/ASP7776F4P5 0UHBI03L.html [in Japanese].

29 Ministry of Defense of Japan, Defense of Japan 2016, 214, www.mod.go.jp/e/publ/w_paper/pdf/ 2016/DOJ2016_2-3-2_web.pdf (site discontinued). 
of what counts as an armed attack is highly controversial, especially in grey-zone situations. For example, if a Chinese military vessel attacked or interfered with a Japanese coastguard vessel that was protecting the Senkakus, would this count as an 'organised and planned' attack against Japan? If a missile launched by North Korea hit a Japanese vessel in Japan's territorial waters or exclusive economic zone, would it be recognised as an armed attack against Japan?

Such ambiguities also exist in the joint planning of the US-Japan alliance. According to a former MSDF chief of staff, there are at least three uncertainties that may create the perception of a gap between the SDF and the US military, especially in grey-zone situations: 1) whether the actions of another country constitute an armed attack, 2) when to begin and end operations by the SDF, and 3) when an armed attack occurs. ${ }^{30}$ Without common understandings of these highly subjective issues between Japanese and American policymakers, significant delays could occur in both countries' responses, creating a gap in the level of deterrence provided by the US-Japan alliance.

Problems also exist regarding the use of force by the SDF. If the Japanese Government recognises 'situations that will have an important influence on Japan's Peace and Security' (or 'important influence situations'), the SDF can provide logistical support, including weapons and ammunition, to the US and its allies. Yet the SDF's logistical support should also be conducted in a 'non-combatant area' and terminated once the area turns into a conflict zone. In principle, these activities need prior approval of the Diet. However, debating whether a situation meets the legal test of having 'an important influence on Japan's peace and security' would necessarily delay deployment of the SDF.

Conversely, if a situation is recognised as 'survival-threatening', the SDF could fully engage with a conflict alongside foreign militaries by exercising collective self-defence. However, such a situation is limited to occasions when:

An armed attack against a foreign country that is in a close relationship with Japan occurs and as a result threatens Japan's survival and poses a clear danger to fundamentally overturn people's right to life, liberty and pursuit of happiness. ${ }^{31}$

30 Tomohisa Takei, 'Gray Zones and Vulnerability in the US-Japan Alliance: Operational and Legal Dimensions', Asia Policy 15(3), July 2020, 25-27, doi.org/10.1353/asp.2020.0041.

31 Ministry of Defense of Japan, Defense of Japan 2016, 219. 
The use of force should be at the 'minimum necessary' level. ${ }^{32}$ Again, whether a conflict in the South China Sea or the Taiwan Strait counted as a 'survival-threatening situation' would likely be a matter of considerable debate.

Of course, military commitment to a war or a conflict is controversial for any country. Such a commitment is based on highly subjective judgements of domestic or international law, as demonstrated by Australia's and NATO's exercise of the right of collective self-defence following the terrorist attacks on 11 September 2001 in the US. Unlike other countries, however, Japan has specified a range of possible SDF responses to various 'situations' (jitai) by taking a 'positive list' approach, rather than a 'negative list' approach. ${ }^{33}$ As already discussed, such an approach could limit the SDF's ability to respond flexibly to actual contingencies that may happen beyond the 'situations' described by the Japanese Government. Indeed, this was one reason the Japanese Government had to draft a new 'special measures law' to dispatch the SDF to the Indian Ocean after the September 11 attacks, for although the government had established the Syuhen-Jitai concept in 1995, it was not applicable to that situation.

These legal impediments could also make it difficult for Japan and the US to conduct the flexible deterrent options (FDO) included in the 2015 defence guidelines. According to the US Joint Chiefs of Staff, FDO aims to avoid a crisis by correctly conveying one's intentions and decisions to the enemy through diplomatic, informational, military and economic channels. If a crisis occurs, FDO seeks to quickly reduce tension and resolve the crisis by strengthening deterrence towards further incursions. ${ }^{34}$ However, because of the legal constraints mentioned above, the SDF could fail to upgrade its responses in line with the US military and in accordance with the escalation of a crisis. In this case, the US-Japan alliance would be seriously damaged at both political and operational levels.

32 Ibid.

33 For the difference between 'positive list' and 'negative list' approaches, see Michael Macarthur Bosack, 'Understanding Japan's "Positive List” Approach to Security', Japan Times, 29 May 2021, www.japantimes.co.jp/opinion/2021/05/29/commentary/japan-commentary/japan-security-laws/. 34 Joint Publication 5-0, Joint Operation Planning, US Joint Chiefs of Staff, 11 August 2011, Appendix E, Flexible Deterrent Options, E-1. 


\section{Japan's Response and its Limits}

Since the end of World War II, Japan has struggled to adjust its defence and security policies to meet changing international realities on the one hand, and ongoing domestic pacifism on the other. ${ }^{35}$ Despite changing strategic circumstances, Japanese policymakers have not touched Article 9 of the constitution, which has been the fundamental element of normative and legal constraints on Japanese security policies. Instead, Japan has taken incremental steps to expand the SDF's activities overseas by introducing 'special measures laws' or by reinterpreting the constitution. Dispatching the SDF to the Indian Ocean for refuelling missions between 2001 and 2010 was a case of the former while allowing the exercise of collective self-defence was a result of the latter.

This incremental approach-which Richard Samuels describes as a 'salami-slicing' strategy—has many limitations, some of which have already been experienced. ${ }^{36}$ As the Diet debate over the constitutionality of collective self-defence demonstrates, enormous amounts of time and energy have already been expended by Japanese policymakers. Although debate is natural and positive under a rule of law, it has deprived the public and policymakers of important opportunities to discuss other essential strategic matters. Moreover, the complexity of the Japanese legal situation could create the perception of a gap between US and Japanese officials' ability to respond to a crisis.

Meanwhile, Japan continues to face growing security threats in its region. In January 2021, China adopted a new coastguard law that authorised the use of weapons by Chinese coastguard ships against foreign vessels on waters claimed by Beijing. It also allowed the Chinese coastguard to seize foreign ships entering those waters. Chinese coastguard ships have apparently been stepping up their 'law enforcement' activities, such as chasing Japanese fishing boats or intercepting Japanese coastguard ships, in waters near the Senkaku Islands, since mid-2020. ${ }^{37}$

35 Soeya Yoshihide, 'Japan: Normative Constraints Versus Structural Imperatives', in Asian Security Practice: Material and Ideational Influences, ed. Muthiah Alagappa (Stanford: Stanford University Press, 1998), 198-233.

36 Richard Samuels, 'Japan's Whack-a-Mole Foreign Policy', The Boston Globe, 30 September 2019.

37 Alessio Patarano, 'What is China's Strategy in the Senkaku Islands?', War on the Rocks, 10 September 2020. 
In response, ruling LDP politicians called for the Japanese Government to strengthen measures to protect Japanese islands, including the use of weapons by Japanese coastguard ships against foreign vessels that do not comply with deportation orders. ${ }^{38}$ While such measures may help to deter China's grey-zone activities, they could also escalate matters beyond grey-zone situations. As already discussed, Japan's legal constraints could inhibit the SDF's ability to respond in a timely and seamless manner to any escalation from grey zone to a more intensified conflict. This could incentivise China to thrust further into Japanese territorial waters, while tactically and carefully avoiding any US military intervention.

Nuclear-armed North Korea also remains an existential threat to Japan. Since his inauguration in 2012, North Korean leader Kim Jong-un has conducted at least 88 missile launches and four nuclear tests. ${ }^{39}$ Meanwhile, North Korea has rapidly advanced its missile and nuclear technologies, including submarine-launched ballistic missiles and an intercontinental ballistic missile that can reach the US homeland. While the Kim government refrained from missile launches after March 2020, it would not be surprising if Pyongyang returned to provocations to extract concessions from the new US administration. Indeed, North Korea launched a seemingly new type of short-range missile for the first time in March 2021. ${ }^{40}$

In sum, Japan's security environment has rapidly deteriorated, while its domestic security reform continues to take a slow and 'incremental' approach. This inevitably makes Japan even more dependent on US protection. Unless Japan takes a significant step towards security reform, enabling it to provide greater flexibility with SDF operations under strict civilian control, the asymmetric nature of the US-Japan alliance will likely continue for the foreseeable future.

38 Reito Kaneko, 'Confirmation of Law on Coast Guard Action Will Help Japan Deter China, Officials Say', Japan Times, 17 March 2021.

39 As of October 2020. See Ministry of Defense of Japan, 'Recent Missile \& Nuclear Development of North Korea', October 2020, www.mod.go.jp/en/d_act/sec_env/pdf/dprk_d-act_e_201111.pdf. 40 'North Korea Claims “New Tactical Guided” Missiles Launched', BBC News, 26 March 2021, www.bbc.com/news/world-asia-56533260. 
This text is taken from Alliances, Nuclear Weapons and Escalation: Managing Deterrence in the 21st Century, edited by Stephan Frühling and Andrew O'Neil, published 2021 by ANU Press, The Australian National University, Canberra, Australia.

doi.org/10.22459/ANWE.2021.08 